\title{
HIGH PD1 EXPRESSION ON CD4 AND CD8 T CELLS ON KAWASAKI COVID-19 POSITIVE CHILDREN AFTER RECOVERY
}

Ana Flávia da Silva Pina ${ }^{1, \star}$, Yhasmin Oliveira Gondim Moraes ${ }^{1}$, Katarine Nicolau Rufca $^{1}$, Rogério do Prado ${ }^{1}$, Luan Cesar Coelho ${ }^{2}$

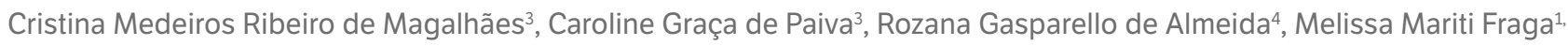
Gleice Clemente1, Maria Isabel de Moraes Pinto ${ }^{1}$, Maria Teresa Terreri ${ }^{1}$

1.Universidade Federal de São Paulo, São Paulo (SP), Brazil; 2.Hospital da Luz, São Paulo (SP), Brazil; 3.Hospital da Criança de Brasília José Alencar, Brasília (DF), Brazil; 4.Universidade Federal do Rio de Janeiro, Rio de Janeiro (RJ), Brazil.

*Corresponding author: anaflaviasilvapina@gmail.com

\section{BACKGROUND}

COVID-19, the disease caused by the SARS-CoV-2, was initially observed with severe clinical manifestations mainly in individuals over 60 years of age and in those with comorbidities. Subsequently, children were diagnosed with SARS-CoV-2 infection and some of them have developed Kawasaki disease in a postinfectious phase. The objective of this study was to investigate the immunological aspects of patients with Kawasaki disease with or without COVID-19 infection.

\section{METHODS}

This is a prospective, multicenter observational study in partnership with five Brazilian pediatric rheumatology services. Thirteen children and adolescents diagnosed with complete or incomplete Kawasaki disease were evaluated in the presence or absence of SARS-CoV-2 infection. An $8 \mathrm{~mL}$-blood sample was collected into EDTA vial before starting intravenous immunoglobulin (IVIg) treatment. After 14 to 21 days of the first blood collection, a new blood sample collection was performed. The immunophenotyping of $\mathrm{T}$ and $\mathrm{B}$ cell was performing by flow cytometry.

\section{RESULTS}

The characteristics of patients, clinical, laboratory and immunological data are described in Table 1.

\section{CONCLUSION}

COVID-19 positive children who develop Kawasaki disease show higher PD1 expression on CD4 T cells and CD8 T cells post IVIG than in those without evidence of COVID-19 infection, suggestive of immune exhaustion.

\section{KEYWORDS}

COVID-19, Kawasaki disease, PD1, CD4, CD8. 
Table 1. Patients with and without COVID-19 analysis.

\begin{tabular}{|c|c|c|c|}
\hline PARAMETER & COVID-19(+) $(n=5)$ & COVID-19(-) $(n=8)$ & p-value \\
\hline Median age (years) & 6 & 1 & \\
\hline Male gender (\%) & $4(80)$ & $5(62.5)$ & \\
\hline Complete Kawasaki (\%) & $3(60)$ & $4(50)$ & \\
\hline Total lymphocytes pre-IVlg (median) & 890.0 & 3347.0 & 0.01 \\
\hline Total neutrophils pre-IVIg (median) & 6072.0 & 10459.5 & 0.11 \\
\hline Platelets pre-IVIg (median) & 165000.0 & 497500.0 & 0.06 \\
\hline Lymphocytes pre-IVIg (median, \%) & 39.1 & 29.4 & 0.61 \\
\hline Lymphocytes post-IVIg (median, \%) & 31.6 & 19.9 & 0.04 \\
\hline Pd1 on cd4 t cell pre-IVIg (median, \%) & 9.2 & 10.2 & 0.66 \\
\hline Pd1 on cd4 $t$ cell post-IVlg (median, \%) & 12.4 & 4.8 & 0.02 \\
\hline Pd1 on cd8 $t$ cell pre-IVIg (median, \%) & 17.1 & 11.0 & 0.77 \\
\hline Pd1 on cd8 $t$ cell post-IVlg (median, \%) & 19.8 & 6.7 & 0.02 \\
\hline Cd19 cell pre-IVIg (median, \%) & 15.4 & 22.6 & 0.38 \\
\hline Cd19 post-IVIg (median, \%) & 15.6 & 15.7 & 0.88 \\
\hline Plasmablasts pre-IVIg (median, \%) & 1.7 & 1.0 & 0.34 \\
\hline Plasmablasts post-IVIg (median, \%) & 3.1 & 0.3 & 0.02 \\
\hline
\end{tabular}

IVlg: intravenous immunoglobulin. 